\title{
ПОРІВНЯЛЬНА ХАРАКТЕРИСТИКА МЕТОДІВ ДОСЛІДЖЕННЯ СОБАК ЗА ДИРОФІЛЯРІОЗУ
}

Кисилиця Владислава Василівна студентка Національний університет біоресурсів і природокористування України (м. Київ, Україна) ORCID: 0000-0001-7754-3706 vladislavakisilitsa@gmail.com

Кладницька Лариса Володимирівна доктор ветеринарних наук, доцент, Національний університет біоресурсів і природокористування України (м. Київ, Україна) ORCID: 0000-0002-9360-0587 kladlarisa@ukr.net

Сорока Наталія Михайлівна доктор ветеринарних наук, профресор, Національний університет біоресурсів і природокористування України (м. Київ, Україна) ORCID: 0000-0003-4659-6666, 5278823@ukr.net

Величко Сергій Володимирович кандидат біологічних наук головний лікар клініки ветеринарної медицини (м. Київ, Україна) ORCID: 0000-0002-2579-2134, wswdoktor@gmail.com

Донцова Ольга Ігорівна лікар клініки ветеринарної медицини (м. Київ, Україна) ORCID:0000-0002-0040-2662 odon@bigmir.net

\section{Величко Владислав Сергійович} студент

Національний університет біоресурсів і природокористування України (м. Київ, Україна)

ORCID: 0000-0002-5227-9168 tvink77777777@gmail.com

Мета роботи - порівняльна характеристика методів дослідження собак за дирофіляріозу. Дослідження проводили на собаках різної статі, порід і вікових груп, власники яких звернулися у клініку ветеринарної медицини. Кров у собак відбирали вранці або ввечері та досліджували на наявність мікродирофілярій за методами Кнотта, роздавленої краплі, Ястреба В. Б. та фрарбування на кислу фоссратазу. Для виявлення збудника Dirofilaria immitis застосовували експрес-тест. Проводили морфологічні та біохімічні дослідження крові, електрокардіографрію і хірургічне видалення псевдопухлини.

За результатами досліджень визначено ефрективність лабораторних методів за дирофріляріозу собак: на циркулюючий антиген - 100 \%, Кнотта - 88,8 \% (p<0,05), роздавленої краплі - 72,2 \% (p<0,05), Ястреба В. Б. - 68,5\% (p<0,001) та фрарбування на кислу фосфратазу - 55,5\% (p<0,001).

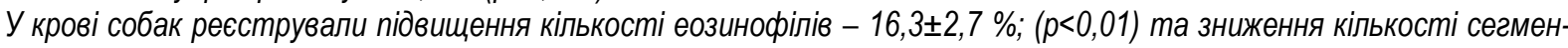

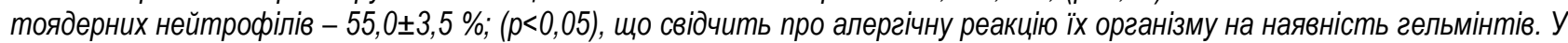

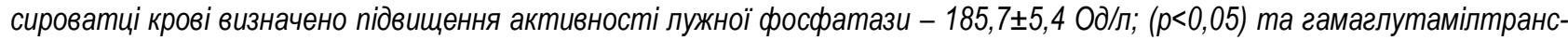

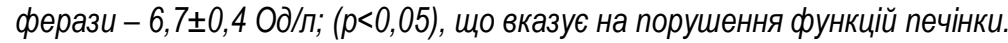

За електрокардіографрії виявлено порушення ритму і провідності серия, які характеризуються синусовою тахікардією (54 \%), мигальною аритмією передсердь (4 \%), екстрасистолією (10\%), фрібриляиією шлуночків (2 \%) та блокадою правої ніжки пучка Гіса (5 \%).

Проведено обстеження псевдопухлини, локалізованої в діляниі сім'яника пса та хірургічне вилучення з піхвової порожнини сім'яника статевозрілого гельмінта Dirofilaria repens.

Ключові слова: дирофріляріоз, мікродирофрілярії, Dirofilaria immitis, Dirofilaria repens, методи дослідження, собаки

DOI: https://doi.org/10.32845/bsnau.vet.2020.3.7

Актуальність. Дирофріляріоз - гельмінтозна хвороба м'ясоїдних тварин, зокрема собак, а також людини, збудни-

ками якої є круглі черви (Genchi, C., Kramer, L. 2017). Найчастіше у собак реєструються два збудники Dirofilaria immitis i Dirofilaria repens, проте їх відомо більше 26 видів (Simon, F., 
Siles, M., Lucas, R., Morchon, J. Gonzalez-Miguel, I. Mellado, E. Carreton, Montoya-Alonso, J. A., 2012). Проміжними хазяями збудників $є$ самки комарів родів Anopheles, Aedes, Culex. Хвороба має значне поширення, особливо в країнах з тропічним та субтропічним кліматом (Panarese, R., Maria, R. I., Latrofa S., Zatell A., Ignjatović Ćupina, A., Montarsi, F., Pombi, M., Mendoza-Roldan, J. A., Beugnet, F., Otranto, D., 2020). Ocновне джерело поширення інвазії - хворі м'ясоїдні тварини. Масове їх ураження гельмінтами спостерігається у період льоту кровосисних комах (весна і перша половина літа) (Simon, F., Siles, M., Lucas, R., Morchon, J. Gonzalez-Miguel, I. Mellado, E. Carreton, Montoya-Alonso, J. A., 2012).

Для успішної діагностики хвороби та лікування тварин важливо чітко розуміти життєвий цикл гельмінтів (McCall, J.W., Kramer, L., Genchi, C., Guerrero, J., Dzimianski, M. T., Mansour, A., McCall, S. D., Carson B. (2014), McCall, J.W., Varloud, M., Hodgkins, E., Mansour A., DiCosty, U., McCall, S., Carmichael, J., Carson, B., Carter, J. 2017). Так збудник Dirofilaria immitis має порівняно довгий цикл розвитку, близько 7-9 місяців і для нього потрібен резервуар або осередок інвазії, переносник, який здатний передавати цю інвазію та сприйнятливий хазяїн. Самка комара, як переносник збудника Dirofilaria immitis, інвазується в той момент, коли живиться кров'ю тварини або людини, що є носієм мікродирофілярій. У самки комара, у мальпігієвих канальцях, мікродирофілярії перетворюються на личинок та проходять три стадії линьки $\left(\mathrm{L}_{1}\right.$, $\mathrm{L}_{2}$ i $\left.\mathrm{L}_{3}\right)$. Личинки третьої стадії підіймаються до хоботка самки комара і передаються собаці або людині через укус комахи (McCall, J.W., Varloud, M., Hodgkins, E., Mansour A., DiCosty, U., McCall, S., Carmichael, J., Carson, B., Carter, J., 2017). Личинки, що потрапляють у кров собаки або людини двічі линяють і перетворюються на мікродирофрілярій. Остання їх линька відбувається на 50-70 добу. Вони мігрують по тілу тварини або людини та досягають легеневої артерії вже на 67 добу. Статева зрілість гельмінтів настає приблизно на 120 добу і вже за 6-9 місяців після зараження у крові собак з'являються мікродирофілярії (American Heartworm Society. Canine guidelines. 2020).

За даними American Heartworm Society статевозрілі дирофрілярії можуть жити в організмі собак до семи років, у котів - до трьох років (American Heartworm Society. Canine guidelines. 2020). Після зараження організм тварини по різному реагує на наявність паразитів. Статевозрілі Dirofilaria immitis локалізуються у правому передсерді, правому шлуночку, легеневій артерії. Вони небезпечні тим, що призводять до порушення роботи серця, утруднюють рух та змінюють тиск крові, а також спричинюють гемоліз еритроцитів.

Клінічні ознаки у собак, як правило, грунтуються на інтенсивності інвазії. Чим вища інтенсивність інвазії, тим важчий загальний стан тварини (American Heartworm Society. Canine guidelines. 2020). Собаки кашляють і легко втомлюються після помірних фрізичних навантажень, особливо тоді, коли дирофілярії заподіюють лише легке пошкодження легеневої артерії. По мірі пошкодження серця рух крові у собак порушується і спричинює серцеву недостатність та раптову загибель.

Статевозрілі Dirofilaria repens локалізуються під шкірою в ділянці очей, в матці, у вигляді псевдопухлин статевих органів собак (Genchi, C., Kramer, L. 2017). Мікродирофрілярії становлять небезпеку для здоров'я тварини, оскільки викликають зміни у внутрішніх органах, а саме, у печінці, нирках, легенях (Mikola, N., Oborina, V., Jokelainen, P. 2020).

Зі змінами клімату та глобального потепління у світі і в Україні зокрема, збільшилась тривалість сезонної активності самок комарів і, тому все частіше, дирофіляріоз реєструється у собак і людини (Jiang, S., Tsikolia, M., Benner, U., Bloomquist J. 2017).

Сучасні дані спеціальної літератури засвідчують, що для діагностики дирофіляріозу в собак найбільш часто використовуються системи експрес-тестів. Крім експрес-тестів, нині відомо чимало методик для визначення дирофрілярій та мікродирофрілярій в організмі собак. Проте не кожна методика забезпечує виявлення гельмінтів в організмі собаки. Деякі 3 цих методик, застосовані після лікування тварини, дають хибні результати, оскільки реагують на циркулюючі імунні комплекси, що залишаються у крові упродовж шести місяців, навіть, після зникнення паразитів. Крім того, окремі методики передбачають використання токсичних і небезпечних реактивів (American Heartworm Society. Canine guidelines. 2020).

У практиці лабораторій ветеринарної медицини давно набув популярності метод Кнотта, який полягає у центрифугуванні крові з $2 \%$ розчином формаліну (1:10) 5 хв за 1500 об/хв. Осад фарбують метиленовим синім і досліджують під мікроскопом [Knott, J. 1939].

Фахівці лабораторій ветеринарної медицини використовують і ряд інших методик, які також знайшли своє місце у дослідженнях за виявлення мікрофрілярій. За методом Кулікова беруть 20 мл венозної крові, змішують з 2 мл 3,8 \% водного розчину лимоннокислого натрію (цитрату натрію) і відстоюють 20-30 хв. При цьому в пробірці утворюється три шари: нижній - еритроцити, середній - лейкоцити і мікрофілярії, верхній - плазма крові. Відбирають піпеткою середній шар, краплями наносять на предметне скло, накривають покривним і досліджують під мікроскопом за малого і середнього збільшення.

Архіпова Д. Р. розробила кількісний метод зажиттєвої діагностики дирофіляріозу собак, який ґрунтується на підрахунку мікрофілярій у лічильній камері Фукс-Розенталя. Лейкоцитарний меланжер до мітки I заповнюють кров'ю і до мітки II розчином, що складається з крижаної оцтової кислоти, розчину фуксину і дистильованої води в співвідношенні 3:4:93. Для рівномірного змішування меланжер з кров'ю і розчином кладуть на вібратор на 2-3 хв. До чистої і сухої камери ФуксРозенталя притирають покривне скло, до появи кілець Ньютона. Розчин у меланжері струшують і краплю розчину (не першу) наносять на середню частину пластинки камери та під мікроскопом (х100) підраховують мікрофілярій у всіх квадратах. Отримане число множать на 6,23 (для 20 мм³ розчину потрібно 6,23 мм³ обсягу камери). Для визначення кількості мікрофілярій в 1 мл крові, отримане число множать на 50 (Архипова, Д. Р. Архипов, И. А. 2004).

За методом Руже-Мюленса до крові додають 95 мл 5 \% розчину формаліну, 5 мл оцтової кислоти і 2 мл концентрованого спиртового розчину генцианвіолету. Суміш центрифугують, надосадову рідину вилучають, а осад знову центрифугують з водою і досліджують під мікроскопом. Слід відмітити, що дослідниками запропонована більш спрощена методика, коли краплю крові поміщають у пробірку з розчином і проводять мікроскопію на наступну добу (Moorhead, A.R., Evans, C.C., Kaplan, R.M. 2017).

За методом Шюфффнера беруть 10 крапель крові і поміщають у 10 мл фрізіологічного розчину, до якого попередньо 
додають кілька крапель розчину сапоніну. Суміш центрифугують (для гемолізу еритроцитів), а живих і рухливих мікрофілярій виявляють в осаді під мікроскопом (The Basics of Heartworm Disease Testing. (2020).

За методом Ястреба В. Б. у пробірку вносять 1 мл стабілізованої антикоагулянтом крові, додають 9 мл дистильованої води і відстоюють 7-10 хв, після чого центрифугують 5 хв за 2000 об/хв. Осад, 0,5 мл, переносять порціями на предметне скло і досліджують під мікроскопом. Виявляють рухливих мікрофрілярій (Ястреб, В. Б. 2004).

Існує також метод аналізу мазка, фарбованого за методом Романовського-Гімза, проте його менше застосовують за діагностики дирофріляріозу.

Метод непрямої імунофлюоресценції (МНІФ, IFA) використовують для виявлення антитіл до мікрофрілярій. Крім того, він має специфічну повноцінність за діагностики дирофіляріозу. За імуноферментного аналізу (IФA, ELISA) можна виявляти антитіла до дирофілярій або сам антиген. Відмічено, що методи МНІФ і ІФА отримали значне поширення у практиці завдяки точності, чутливості, специфічності та швидкості діагностики. Проте після успішного лікування тварини за дирофіляріозу методи ІФА (1 рік) і МНІФ (6 місяців) дають позитивний результат за повторного дослідження (Nelson, C.T., McCall, J.W., Jones S., Moorhead, A. 2020).

Пряма мікроскопія краплі свіжої крові за малого збільшенням мікроскопа, є найбільш легким, зручним і швидким методом діагностики дирофріляріозу. Рухливі мікрофрілярії добре помітні за їх пересуванням між еритроцитами. Цей метод дає надійні результати тільки за високої інтенсивності інвазії (The Basics of Heartworm Disease Testing. 2020).

Для дослідження сироватки крові в пробірку беруть кілька мл венозної крові. Остання згортається і мікрофілярії мігрують у сироватку. Для цього сироватку із згустком відстоюють у пробірці кілька годин. Потім пастерівською піпеткою беруть кілька крапель сироватки з дна пробірки або з місця на межі сироватки і згустку та поміщають на предметне скло, накривають покривним скельцем і досліджують за малого збільшенням мікроскопа. Виявляють рухливих мікрофілярій (Nelson, C.T., McCall, J.W., Jones S., Moorhead, A. 2020).

За методу фарбування на кислу фоссратазу (набір для цитохімічного фрарбування препаратів червоного кісткового мозку на кислу фосфатазу «ДіахімЦитоСтейн-КФ») у пробірку з 10 мл дистильованої води додають кілька крапель сироватки крові, перемішують, центрифугують 5 хв за 1000 1500 об/хв. Після чого надосадову рідину вилучають, а осад розміщують на предметному склі, висушують, фріксують в парах формаліну 30 c, фарбують, дотримуючись інструкції до набору для фрарбування (Nelson, C.T., McCall, J.W., Jones S., Moorhead, A. 2020).

Імунохроматограффічний експрес-тест призначений для одноетапного якісного виявлення дирофрілярій (CHW Ag) у крові, сироватці, плазмі. Тести виявляють протеїн (антиген), який секретується, дорослими самками Dirofilaria immitis. Цей тест є одним з найбільш чутливих методів діагностики. Для цього потрібно звільнити касету з пакета і покласти горизонтально, внести 3 краплі досліджуваного зразка у віконце тестсистеми. Облік результатів проводити за 5-10 хв (Nelson, C.T., McCall, J.W., Jones S., Moorhead, A. 2020, FDA. 2020).

Для отримання додаткових даних щодо стану здоров'я тварини за дирофріляріозу проводять електрокардіогра- фію, ультразвукову діагностику, рентгенографію. За ехографії виявляють дирофілярій у камерах серця, зазвичай у лівому передсерді, легеневій артерії; визначають об'єм камер серця, товщину міжшлуночкової перегородки та міокарда за фаз серцевих скорочень. За високої інтенсивності інвазії, коли гельмінти локалізуються в легеневих артеріях, правому шлуночку і правому передсерді, спостерігають гіпертрофрію або розширення правого шлуночка, перикардіальний випіт, парадоксальну рухливість міжшлуночкової перегородки, сплющування і потовщення перегородки, недостатність тристулкового клапана, підвищення тиску в легеневих артеріях (Ashley, B., Saunders, D. Wesselowski, S., Cusack, K. 2020).

За дослідження біострумів серця визначають електричну вісь серця, зміни в роботі камер серця, провідної системи. Відмічено, що за дирофіляріозу у собак електрокардіографія виявляє синусову аритмію (тахікардію), ознаки розширення правого шлуночка і правого передсердя, порушення провідності (American Heartworm Society. Canine guidelines. 2020).

Для вилучення гельмінтів, що локалізуються під шкірою і формують псевдопухлини, застосовують хірургічні методи.

Треба зазначити, що не кожна з запропонованих методик може забезпечувати виявлення мікродирофрілярій або дирофрілярій в організмі собак, особливо після проведеного їх лікування (American Heartworm Society. Canine guidelines. 2020).

Морфологічні та біохімічні дослідження крові не дозволяють поставити точний діагноз на дирофіляріоз, але допомагають визначити патологічні зміни в органах і тканинах, які можуть бути пов'язані з інвазією. Найбільш часто за дирофіляріозу відзначають нормоцитарну, нормохромну або гіпохромну анемію (гематокрит $<20-30 \%$ ), гемолітичну анемію, нейтрофілію, еозиносрілію (85\% випадків), базофілію (60\% випадків), моноцитоз, тромбоцитопенію. У важких випадках, особливо, якщо присутня серцева недостатність, підвищується активність ферментів АлАТ і АсАТ, іноді відзначається гіпербілірубінемія. Азотемія може бути не ниркового походження, якщо присутні дегідратація або порок серця, або може бути вторинна за гломерулонефриту, який ускладнює клінічну картину([Oi, M., Yoshikawa, S., Ichikawa, Y., Nakagaki K., Matsumoto, J., Nogami, S. 2014).

Рентгенографія грудної порожнини за оцінкою патологічних змін у легенях дозволяє побічно визначити ступінь інвазії. У собак, хворих на дирофіляріоз, можна виявити потовщення легеневої артерії, ії звивистість та гіпертрофію правого шлуночка, ущільнення тканини легені. Для кращої демонстрації змін у судинах можна провести ангіографію. Слід відмітити, що рентгенографія показує поширеність запального процесу в легенях і виявляє хворих тварин з високим ризиком розвитку легеневої тромбоемболії (Atsumi, E., Matsumoto, H., Taira, N., Yohena, T.,Kawasaki H., Kawabata, T., Yoshimi, N., 2019).

Також вагомим фактором своєчасного виявлення Dirofilaria immitis i Dirofilaria repens в організмі собак $є$ те, що хворі тварини $є$ резервуаром цих гельмінтів, які небезпечні для людини.

Отже, визначення оптимального алгоритму лабораторного і діагностичного дослідження собак за дирофріляріозу набуває все більшої актуальності в зв'язку з поширенням його на території України 
Матеріали і методи досліджень. Дослідження проводили у міжкафедральній лабораторії факультету ветеринарної медицини НУБіП України та у клініці ветеринарної медицини міста Києва упродовж 2020 року. Для досліджень відібрали 53 собаки різних порід, власники яких звернулись за допомогою в клініку. Дослідження проводили з дотримання вимог Закону України № 3447-IV від 21.02.2006 р. «Про захист тварин від жорстокого поводження» відповідно до «Європейської конвенції щодо захисту хребетних тварин, що використовуються для експериментальних та наукових цілей» (Страсбург, 1986), декларації «Про гуманне ставлення до тварин» (Гельсінкі, 2000) і Національного конгресу з біоетики «Загальні етичні принципи експериментів на тваринах» (Київ, 2001).

Проводили загальний клінічний огляд собак, відбирали кров з додаткової підшкірної вени передпліччя вранці або ввечері. Кров досліджували лабораторно імуноферментним методом (система експрес-тесту) на наявність антигену дорослих гельмінтів та за методами Кнотта, роздавленої краплі, центрифугування з дистильованою водою, фарбування на кислу фоссратазу на наявність мікродирофілярій.

За дослідження методом Кнотта до 1 мл крові собак додавали 10 мл 2\%-ного розчину формаліну, центрифугували протягом 5 хвилин за 1500 об/хв. Після цього надосадову рідину вилучали, а осад фарбували метиленовим синім і досліджували під мікроскопом (Knott, J. 1939).

За дослідження методом роздавленої краплі, пробірки 3 кров'ю струшували, відбирали 3 краплі крові, які наносили на предметне скло, зверху накривали покривним скельцем і одразу досліджували під малим збільшенням мікроскопу.

За методом Ястреба В.Б. 1 мл стабілізованої антикоагулянтом крові (цитрат натрію, гепарин, етилендиметилтетраоцтова кислота) вносили в пробірку, додавали 9 мл дистильованої води і відстоювали 7-10 хвилин, після чого центрифугували протягом 5 хвилин за 2000 об /хв. Осад у кількості 0,5 мл розміщали порціями на предметному склі та проводили мікроскопію (Ястреб, В. Б. 2004).
За дослідження методом фарбування на кислу фосфратазу в пробірку з 10 мл дистильованої води додавали кілька крапель сироватки і центрифугували 5 хв. за 1000-1500 об/хв, надосадову рідину вилучали, ресуспендований осад розміщали на предметному склі, висушували, фіксували в парах формаліну 30 с, фрарбували, дотримуючись інструкції до набору для фрарбування (Nelson, C.T., McCall, J.W., Jones S., Moorhead, A. 2020).

За дослідження експрес-тестом на дослідження наявності антигену Dirofilaria immitis в крові собак наносили краплю сироватки крові досліджуваної тварини у спеціальне віконце тест-системи, очікували 5-15 хвилин і враховували результат за наявністю або відсутністю смужки у відповідній зоні тестової системи (American Heartworm Society. Canine guidelines. 2020).

Усіх собак, у яких був позитивний результат за експрес-тесту на антиген в крові, досліджували іншими, вище зазначеними методами, з метою виявлення їх ефективності. Методом електрокардіографії визначали функціональний стан серця (Nelson, C.T., McCall, J.W., Jones S., Moorhead, A. 2020). Хірургічним методом досліджували псевдопухлини та вилучали з них статевозрілі диросрілярії (Napoli, E., Bono, V., Gabriella Gaglio, Salvatore Giannetto, Antonina Zanghì, Domenico Otranto, Emanuele Brianti. 2019). Морфологічні та біохімічні показники крові визначали за допомогою загально відомих методик (Влізло, В. В., Федорук, Р. С., Ратич, І. Б. та інші. 2012).

Одержані цифрові дані опрацьовували статистично 3 визначенням середньоарифметичної величини (М), її похибки (m). Достовірність різниці середніх значень встановлювали за критерієм Стьюдента. Зміни показників вважали достовірними за $p<0,05$ (у тому числі, $p<0,01$ і $p<0,001$ ).

Результати власних досліджень. Як показали результати досліджень у крові собак за дослідження крові з використанням експрес-тесту позитивні результати на наявність антигену Dirofilaria immitis отримали у 53 собак, що становило $100 \%$ (рис. 1).

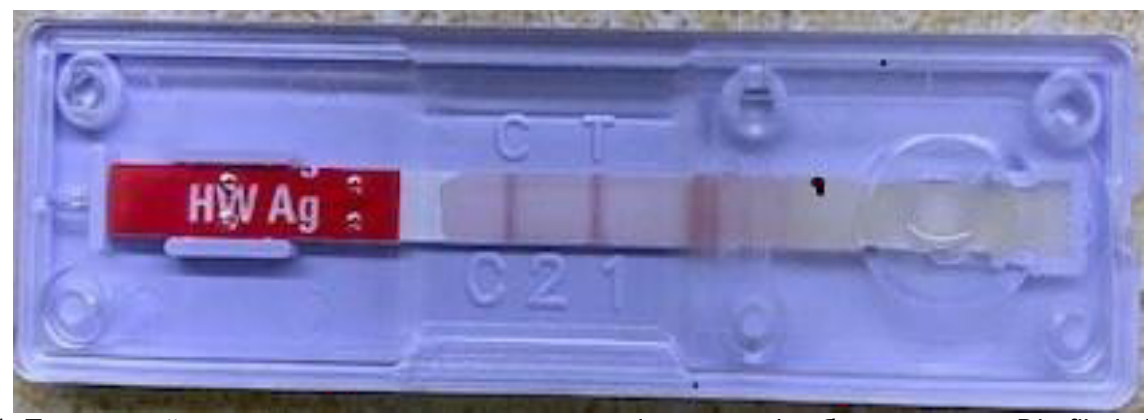

Рис. 1. Позитивний результат експрес-тесту на наявність у крові собаки антигену Dirofilaria immitis

За використання методу Кнотта виявляли мікродирофілярій у 88,8 \% (p<0,05) випадків порівняно з методом дослідження на циркулюючий антиген за експрес-тестом. На нашу думку, такі показники обумовлені тим, що бувають випадки паразитування тільки статевозрілих гельмінтів, а мікродирофілярії відсутні внаслідок проведеного попереднього лікування собак.

За дослідження методом роздавленої краплі мікродирофілярії були виявлені у $72,2 \%(p<0,01)$ собак. Методом
Ястреба В. Б. виявляли мікродирофілярії у $68,5 \%$ (р<0,001) випадків, а за фарбування на кислу фосфатазу - у $55,5 \%$ $(p<0,001)$.

За результатами морфологічного дослідження крові

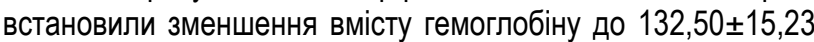
г/л $(p<0,01)$ та тенденцію до зменшення кількості еритроцитів порівняно з контролем (табл. 1). 
Таблиця 1

Морфологічні показники крові собак за дирофіляріозу, Mm, n=17

\begin{tabular}{|c|c|c|}
\hline \multirow{2}{*}{ Показники } & \multicolumn{2}{|c|}{ Група собак } \\
\cline { 2 - 3 } & контрольна & дослідна \\
\hline Еритроцити, Т/л & $6,27 \pm 0,44$ & $5,82 \pm 0,95$ \\
\hline Гемоглобін, г/л & $149,50 \pm 10,13$ & $132,50 \pm 15,23^{*}$ \\
\hline Лейкоцити, Г/л & $9,23 \pm 0,275$ & $9,7 \pm 0,19$ \\
\hline
\end{tabular}

Примітка. Достовірна різниия порівняно з контролем ${ }^{*} p<0,05,{ }^{* *} p<0,01,{ }^{* * *} p<0,001$.


відмічали достовірне підвищення кількості еозинофілів -

16,3 $\pm 2,7 \%$; (p<0,01), зниження кількості сегментоядерних

Таблиця 2

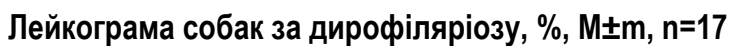

\begin{tabular}{|c|c|c|}
\hline \multirow{2}{*}{ Показники } & \multicolumn{2}{|c|}{ Група собак } \\
\hline & контрольна & дослідна \\
\hline Нейтрофріли паличкоядерні & $3,0 \pm 0,9$ & $1,0 \pm 0,6$ \\
\hline сегментоядерні & $71,7 \pm 3,8$ & $55,0 \pm 3,5^{*}$ \\
\hline Еозинофріли & $2,0 \pm 0,6$ & $16,3 \pm 2,7^{\star *}$ \\
\hline Моноцити & $3,0 \pm 0,9$ & $3,0 \pm 0,9$ \\
\hline Лімфоцити & $21,3 \pm 2,1$ & $25,0 \pm 1,16$ \\
\hline Базофріли & 0 & 0 \\
\hline
\end{tabular}

Примітка. Достовірна різниця порівняно з контролем ${ }^{*} p<0,05,{ }^{* *} p<0,01,{ }^{* * *} p<0,001$.

За біохімічних досліджень у сироватці крові встановлено достовірне підвищення активності лужної фоссфатази
$185,7 \pm 5,4 \quad$ Од/л; $\quad(p<0,05)$ та гамаглутамілтрансфрерази $6,7 \pm 0,4$ Од/л; $(p<0,05)$ порівняно з контролем (табл. 3).

Таблиця 3

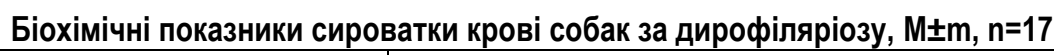

\begin{tabular}{|l|c|c|}
\hline \multicolumn{1}{|c|}{ Показники } & \multicolumn{2}{|c|}{ Група собак } \\
\cline { 2 - 3 } & \multicolumn{2}{|c|}{ контрольна } \\
\hline АсАТ, Од/л & $45,04 \pm 8,65$ & $25,6 \pm 5,47$ \\
\hline АлАТ, Од/л & $25,03 \pm 4,39$ & $31,80 \pm 5,52$ \\
\hline Лужна фросфатаза, Од/л & $136,3 \pm 10,3$ & $185,7 \pm 5,4^{*}$ \\
\hline Гамаглутамлтрансфераза, Од/л & $2,3 \pm 1,0$ & $6,7 \pm 0,4^{*}$ \\
\hline Амілаза, Од/л & $949,7 \pm 245,5$ & $1143,1 \pm 296,8$ \\
\hline Креатинін, мкмоль/л & $78,2 \pm 15,0$ & $78,5 \pm 14,36$ \\
\hline Сечовина, ммоль/л & $5,42 \pm 0,92$ & $7,85 \pm 1,04$ \\
\hline Білок загальний, г/л & $58,22 \pm 2,70$ & $65,82 \pm 2,34$ \\
\hline Альбумін, г/л & $3,9 \pm 1,1$ & $3,6 \pm 0,9$ \\
\hline Глюкоза, ммоль/л & $4,33 \pm 0,75$ & $6,20 \pm 0,25$ \\
\hline Білірубін загальний, мкмоль/л & $3,8 \pm 1,7$ & $4,3 \pm 1,2$ \\
\hline Білірубін прямий, мкмоль/л & $1,1 \pm 0,3$ & $1,7 \pm 0,9$ \\
\hline Р, ммоль/л & $1,4 \pm 0,5$ & $1,9 \pm 1,1$ \\
\hline Са, ммоль/л & $2,4 \pm 0,5$ & $2,01 \pm 0,7$ \\
\hline
\end{tabular}

Примітка. Достовірна різниця порівняно з контролем ${ }^{*} p<0,05,{ }^{* *} p<0,01,{ }^{* * *} p<0,001$.

На рис. 2 і 3 представлено кардіограми дослідних собак за ураження їх гельмінтами Dirofilaria immitis. За результатами електрокардіографії у собаки Кари частота серцевих скорочень $є$ нерегулярною від 160 до 280 уд./хв. Слід відмітити, що електрична вісь серця не відхилена; ритм нерегулярний, відмічається фібриляція передсердь. Екстрасистоли мономорфні, поодинокі, шлуночкові (з лівого шлуночка), за типом блокади правої ніжки пучка Гіса; реєструється 25 екстрасистол за 5 хв.

За результатами електрокардіографрічних досліджень частота серцевих скорочень собаки Оскара становила 120140 уд./хв. Електрична вісь серця не відхилена. Серцевий ритм нерегулярний; дихальна синусова аритмія; екстрасистолія. Мономорфні екстрасистоли правого шлуночка за типом блокади лівої ніжки пучка Гіса; Екстрасистоли поодинокі та куплети, епізоди тригіменії, квадригіменії, вислизаючі; неповна компенсаторна пауза після кожної екстрасистоли; реєструється 103 екстрасистоли за 6 хв; значне підвищення кількості екстрасистол відмічається за занепокоєння тварини. Виявляються ознаки гіпертрофії лівого передсердя. У той же час вище зазначені зміни в роботі серця собак є супутніми за дирофріляріозу і не дають можливість точно встановити діагно3. 


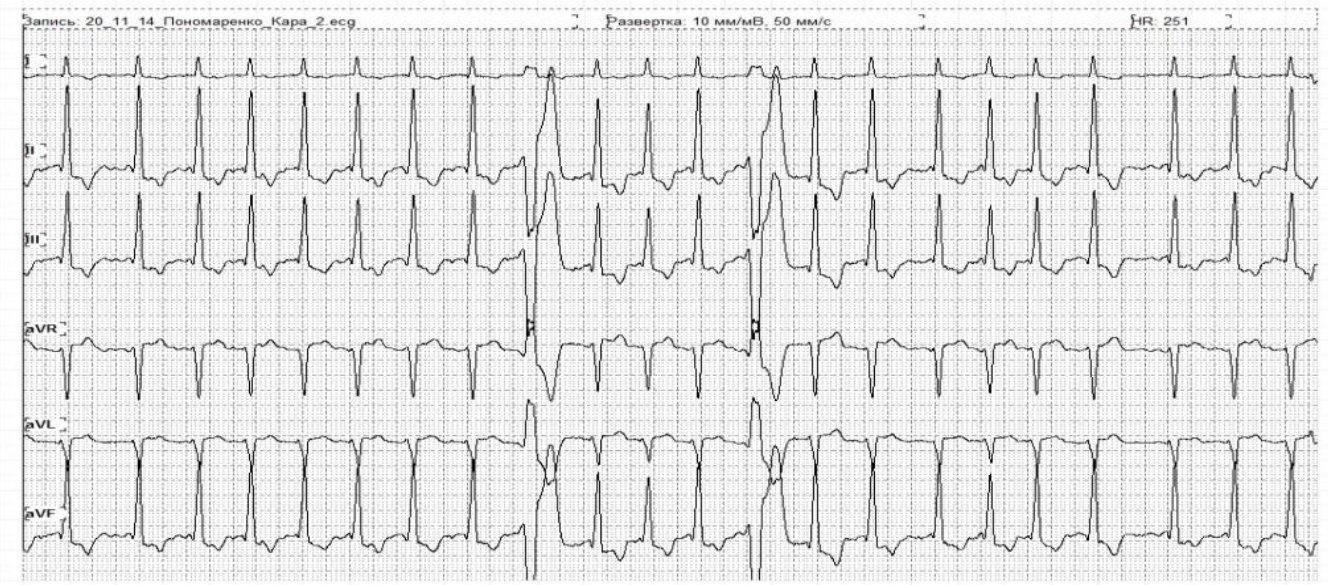

Рис. 2. Електрокардіограма собаки Кари за дирофріляріозу

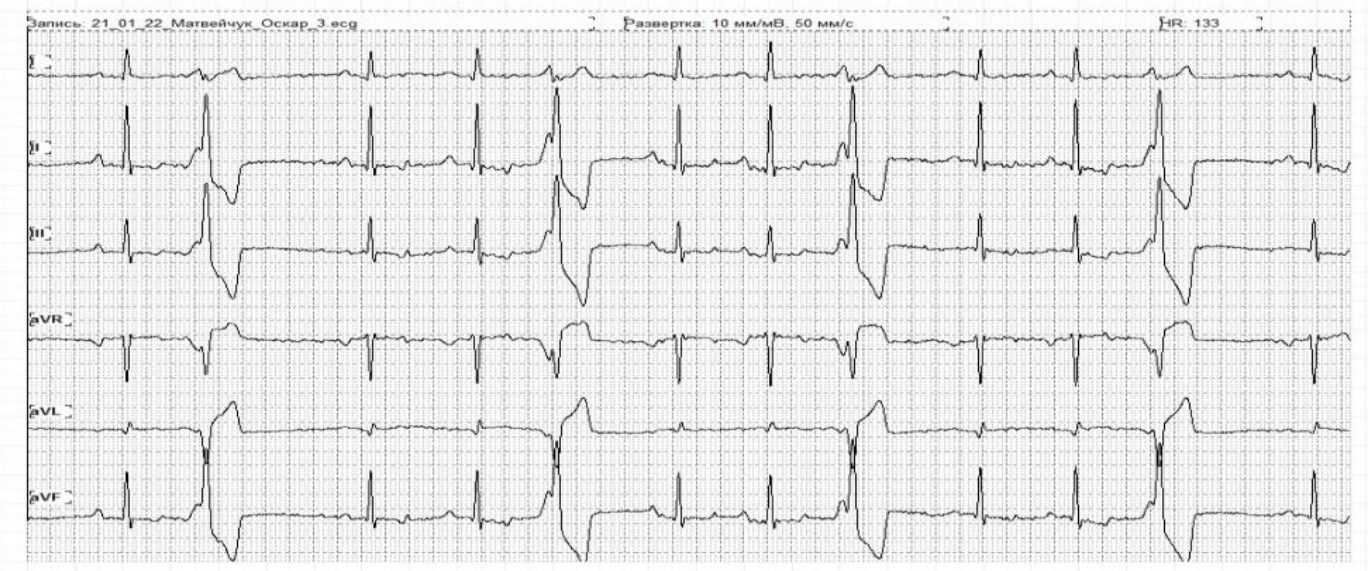

Рис. 3. Електрокардіограма собаки Оскара за дирофіляріозу

Методом електрокардіографії у дослідних собак встановлено порушення ритму і провідності серця, що проявлялося синусовою тахікардією у 54 \%, миготливою аритмією передсердь - у $4 \%$, екстрасистолією - у $10 \%$, фібриляцією шлуночків - у $2 \%$ та блокадою правої ніжки пучка Гіса - у 5
$\%$.

За використання хірургічного втручання дослідили псевдопухлину, яка була локалізована в ділянці сім'яника пса, та видалили піхвової порожнини сім'яника гельмінта Dirofilaria repens (puc. 4, 5).

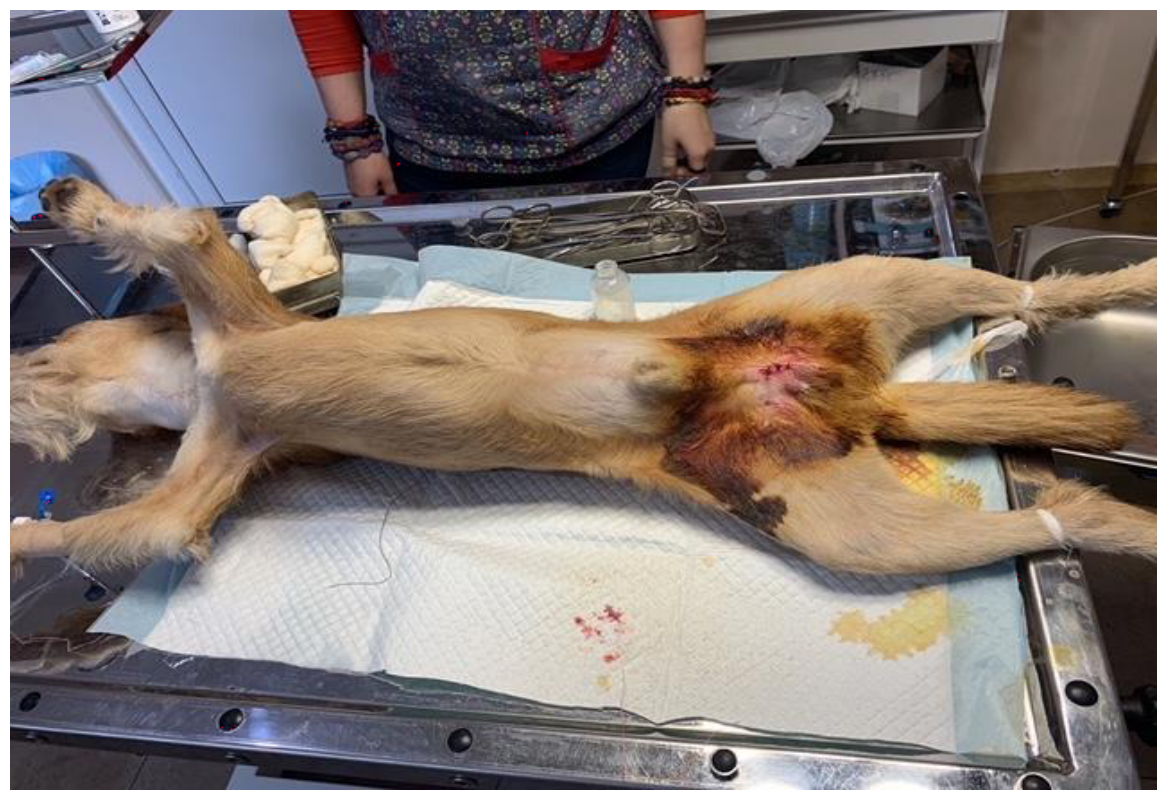

Рис. 4. Собака за хірургічного втручання за видалення псевдопухлини сім'яника 

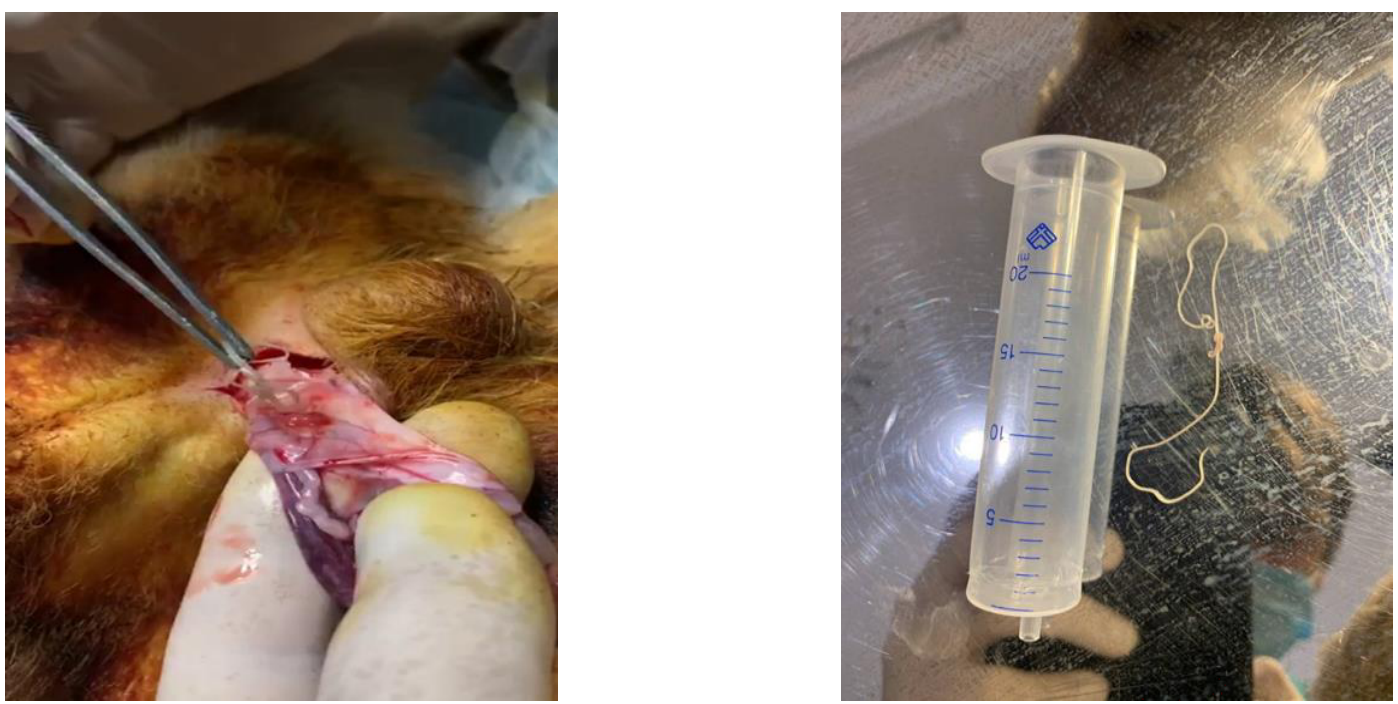

Рис. 5. Видалення псевдопухлини та гельмінта Dirofilaria repens

Дорослі особини гельмінта Dirofilaria repens, як правило, локалізуються підшкірно, хоча їх також можна виявити в черевній порожнині та в сполучних м'язових фасціях, де вони досягають статевої зрілості. Отже, виявлення Dirofilaria repens в організмі собак, свідчить про те, що вони є резервуарами для цього виду гельмінтів і тим самим створюють небезпеку для людини.

Обговорення. Нині відомо ряд методик, які традиційно використовуються у діагностичних дослідженнях собак за дирофріляріозу. Не всі методики дослідження $є$ ефективними для встановлення діагнозу. За дослідження собак на дирофріляріоз нами використані методи лабораторної діагностики, зокрема метод Кнотта, роздавленої краплі крові, Ястреба В. Б., фрарбування на кислу фоссратазу та експрес-тест. За результатами досліджень найбільш точним було використання експрес-тесту, його ефективність становила $100 \%$. Це узгоджується $з$ даними інших дослідників (American Heartworm Society. Canine guidelines. 2020). За інших методів лабораторної діагностики результати були різні. Так за методу Кнотта ефрективність становила 88,8 \%, роздавленої краплі $72,2 \%$, Ястреба В. Б. - 68,5 \%, на кислу фосфратазу - 55,5 \%. Зазначені методи дозволяють виявляти мікрофрілярії у крові собак та діагностувати у них дирофіляріоз. Проте, за даними іноземних авторів, ці методики не отримали широкого використання у практиці лікарів ветеринарної медицини (Nelson, C.T., McCall, J.W., Jones S., Moorhead, A. 2020). Ha нашу думку, метод Кнотта $є$ найефективнішим, оскільки експрес-тести реагують лише на статевозрілих гельмінтів Dirofilaria immitis та можуть давати позитивні результати після лікування собак упродовж 6 місяців через їх циркулюючий антиген у крові (Savadelis, M.D., Day, K.M., Bradner, J.L., Wolstenholme, A. J., Dzimianski, M. T., Moorhead A, .R. 2018).

Додаткові методи діагностики дозволяють виявити супутні патологічні зміни в окремих органах собак за дирофіляріозу. Морфологічне дослідження крові собак показало підвищення кількості еозинофілів, які є маркерами паразитарних хвороб і здатні знищувати токсини чужорідного походження. Біохімічні показники сироватки крові собак, зокрема достовірне підвищення активності лужної фоссратази та гамаглутамілтрасферази засвідчили захворювання печінки, яке може бути інтеркурентним за дирофіляріозу (Panarese, R., Maria, R. I., Latrofa S., Zatell A., Ignjatović Ćupina, A., Montarsi, F.,
Pombi, M., Mendoza-Roldan, J. A., Beugnet, F., Otranto, D. 2020).

За електрокардіографії відмічається зниження функціональної активності серцевого м'яза, що збігається з результатами досліджень інших авторів (Ashley, B., Saunders, D. Wesselowski, S., Cusack, K. 2020).

За хірургічного втручання досліджено псевдопухлину, яка локалізувалася на сім'яному канатику та вилучено статевозрілого гельмінта Dirofilaria repens 3 піхвової порожнини сім'яника. За даними літератури, сім'яники можуть бути місцем локалізації гельмінтів Dirofilaria repens (Napoli, E., Bono, V., Gabriella Gaglio, Salvatore Giannetto, Antonina Zanghì, Domenico Otranto, Emanuele Brianti. 2019).

Отримані результати досліджень свідчать, що постановка діагнозу на дирофіляріоз, лише за клінічними ознаками неможлива, оскільки вони не завжди є характерними. Проте зміни у функціонуванні серцево-судинній системі, наявність псевдопухлин, зміни у морфологічних і біохімічних показниках крові можуть свідчити про ураження собак дирофріляріями та мікродирофріляріями. Тому для встановлення остаточного діагнозу собакам слід проводити комплекс діагностичних методів досліджень на дирофіляріоз.

\section{Висновки.}

У роботі наведено вирішення важливої науково-практичної проблеми, а саме проведено комплексне лабораторне дослідження крові собак на дирофріляріоз методом дослідження на циркулюючий антиген, Кнотта, роздавленої краплі, чутливості на кислу фоссратазу. Визначено морфологічні, біохімічні показники крові собак, проведено електрокардіографічні дослідження за дирофіляріозу. Хірургічним методом досліджено псевдопухлину, з якої вилучено Dirofilaria repens.

1.Визначено ефективність застосування лабораторних методів досліджень собак за дирофіляріозу. Ефективність методу на циркулюючий антиген становила $100 \%$, Кнотта - 88,8\% ( (р<0,01), Ястреба В. Б. - 68,5\% ( $<<0,001)$, фрарбування на кислу фоссратазу $-55,5 \%$ ( $p<0,001)$.

2.У крові собак за дирофіляріозу реєстрували збіль-

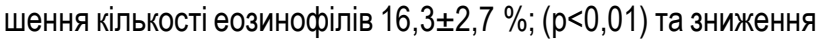
кількості сегментоядерних нейтрофрілів $55,0 \pm 3,5 \%$; (p<0,05), що засвідчує алергічну реакцію в їх ор- 
ганізмі, яка характерна за гельмінтозів. У сироватці крові відмічали підвищення активності лужної фосфратази $185,7 \pm 5,4$ Од/л; $\quad(p<0,05)$ та гамаглутамілтрансфрерази $6,7 \pm 0,4$ Од/л; ( $<<0,05)$, що характеризує порушення функціонування печінки.

3.Методом електрокардіографії виявлено порушення ритму і провідності серця у собак за дирофіляріозу, яке проявлялося синусовою тахікардією - $54 \%$, мигальною аритмією передсердь - 4 \%, екстрасистолією (10\%), фрібриляцією шлуночків (2 \%) та блокадою правої ніжки пучка Гіса (5 \%).

4.3а хірургічного втручання видалено псевдопухлину, яка локалізувалася в ділянці сім'яника, та вилучено з піхвової порожнини сім'яника гельмінта Dirofilaria repens.

\section{https://d3ft8sckhnqim2.cloudfront.net/images/pdf/2020_AHS_Canine_Guidelines_Summary_11_12.pdf? 1605556516 \\ Canine guidelines. (2020). Available at: \\ 2.Genchi, C., Kramer, L. (2017). Subcutaneous dirofilariosis (Dirofilaria repens): an infection spreading throughout the old

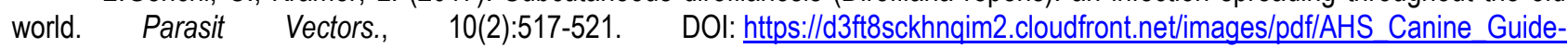

lines 11 1320.pdf?1605556516

3.Simon, F., Siles, M., Lucas, R., Morchon, J., Gonzalez-Miguel, I. Mellado, E. Carreton, Montoya-Alonso, J. A. (2012). Human and animal dirofilariasis: the emergence of a zoonotic mosaic. Clin Microbiol Rev., 25:507-544.

4.Panarese, R., Maria, R. I., Latrofa S., Zatell A., Ignjatović Ćupina, A., Montarsi, F., Pombi, M., Mendoza-Roldan, J. A., Beugnet, F., Otranto, D. (2020). Hyperendemic Dirofilaria immitis infection in a sheltered dog population: an expanding threat in the Mediterranean region. International Journal for Parasitology., 50(8):555-559. DOl: https://doi.org/10.1016/.j.jpara.2020.04.002

5. Knott, J. (1939). A method for making microfilarial surveys on day blood. Trans. Roy. Soc. Trop. Med. Hyg., 33:191-196.

6. Mikola, N., Oborina, V., Jokelainen, P. (2020). Knowledge about emerging zoonotic vector-borne parasites Dirofilaria immitis and Dirofilaria repens in Finland: questionnaire survey to medical doctors and veterinarians. Vector Borne Zoonotic Dis., 20:2732. DOI: https://doi.org/10.1089/vbz.2019.2502

7. Moorhead, A.R., Evans, C.C., Kaplan, R.M. 2017. A diagnostic algorithm for evaluating cases of potential macrocyclic lactone-resistant heartworm. Parasit Vectors., 10 (2): 479.

8. The Basics of Heartworm Disease Testing. (2020). DOl: https://tvmdl.tamu.edu/2020/05/21/the-basics-of-heartworm-disease-testing/.

9. Atsumi, E., Matsumoto, H., Taira, N., Yohena, T.,Kawasaki H., Kawabata, T., Yoshimi, N. 2019. Thirteen cases of pulmonary dirofilariosis in a single institution in Okinawa Island. Virchows Archiv. 475: 335-340.,DOl: https://doi.org/10.1007/s00428019-02614-9

10. Oi, M., Yoshikawa, S., Ichikawa, Y., Nakagaki K., Matsumoto, J., Nogami, S. (2014) Prevalence of Dirofilaria immitis among shelter dogs in Tokyo, Japan, after a decade: comparison of 1999-2001 and 2009-2011. Parasite. 21:10., DOl: https://doi.org/10.1051/parasite/2014008

11. Ashley, B., Saunders, D. Wesselowski, S., Cusack, K. (2020). Transesophageal Echocardiography-Guided Dirofilaria immitis Extraction from the Right Atrium in a Dog. CASE. 4(4):299-302,. DOl: https://doi.org/10.1016/j.case.2020.05.005

12. Napoli, E., Bono, V., Gabriella Gaglio, Salvatore Giannetto, Antonina Zanghì, Domenico Otranto, Emanuele Brianti. (2019). Unusual localization of Dirofilaria repens (Spirurida: Onchocercidae) infection in the testicle of a dog Comparative Immunology, Microbiology and Infectious Diseases., 66 :101326. DOI: https://doi.org/10.1016/i.cimid.2019.06.007

13. Nelson, C.T., McCall, J.W., Jones S., Moorhead, A. (2020). Current Canine Guidelines for the Prevention, Diagnosis and Management of Heartworm Infections in Dogs. DOI: https://d3ft8sckhnqim2.cloudfront.net/images/pdf/2020 AHS Canine_Guidelines.pdf?1580934824

14. FDA. (2020). Keep the Worms Out of Your Pet's Heart! The Facts about Heartworm Disease. Available from: DOI: https://www.fda.gov/ animal-veterinary/animal-health-literacy/keep-worms-out-yourpets-heart-facts-about-heartworm-disease

15. Jiang, S., Tsikolia, M., Benner, U., Bloomquist J. (2017) Mosquitocidal activity and mode of action of the isoxazoline fluralaner. Int J Environ Res Public Health., 14:154. Doi: 10.3390/ijerph14020154.

16. McCall, J.W., Kramer, L., Genchi, C., Guerrero, J., Dzimianski, M. T., Mansour, A., McCall, S. D., Carson B. (2014). Effects of doxycycline on heartworm embryogenesis, transmission, circulating microfilaria, and adult worms in microfilaremic dogs. Vet Parasitol., 206(1-2):5-13.

17. McCall, J.W., Varloud, M., Hodgkins, E., Mansour A., DiCosty, U., McCall, S., Carmichael, J., Carson, B., Carter, J. (2017). Shifting the paradigm in Dirofilaria immitis prevention: blocking transmission from mosquitoes to dogs using repellents/insecticides and macrocyclic lactone prevention as part of a multimodal approach. Parasit Vectors., 10(2):525.

18. Savadelis, M.D., Day, K.M., Bradner, J.L., Wolstenholme, A. J., Dzimianski, M. T., Moorhead A, .R. (2018). Efficacy and side effects of doxycycline versus minocycline in the three dose melarsomine canine adulticidal heartworm treatment protocol. Parasit Vectors., 11:671.

19. Arkhypova, D. R., Arkhypov, Y. A., (2004). Kolychestvennыi metod dyahnostyky dyrofyliaryoza sobak. [Quantitative method for diagnosing heartworm disease in dogs]. Trudy Vseros. yn-ta helmyntolohyy ym. K.Y. Skriabyna. [Abstracts. Russian Institute of Helminthology named by K.Y. Skriabyn], 40, 18-22. (in Russian).

20. Vlizlo, V. V., Fedoruk, R. S., Ratych, I. B. ta inshi. (2012). Laboratorni metody doslidzhen u biolohii, tvarynnytstvi ta veterynarnii medytsyni. [ Laboratory research methods in biology, animal husbandry and veterinary medicine]. Lviv «Spolom». [Lviv "Spolom"]. 764. (in Ukrainian).

21. Yastreb, V. B. (2004). Nekotorbe aspektы эpyzootolohyy dyrofyliaryoza sobak v Moskovskom rehyone. [Some aspects of 
the epizootology of heartworm disease in dogs in the Moscow region]. Teoryia y praktyka borbы s parazytarnыmy bolezniamy. [Theory and practice of control of parasitic diseases. Abstracts. scien. conf. Moscow]. 5. 440-442. (in Russian).

Vladislava Kysylytsia, student, NULES of Ukraine, Kyiv

Larysa Kladnytska, Doctor of Veterinary Sciences, Associate Professor, Kyiv

Natalia Soroka, Doctor of Veterinary Sciences, Professor, NULES of Ukraine, Kyiv

Serhiy Velychko, PhD in Biological Sciences, Chief Physician of the Veterinary Medicine Clinic, Kyiv,

Olga Dontsova, Doctor of Veterinary Medicine Clinic, Kyiv

Vladyslav Velychko, student, NULES of Ukraine, Kyiv

DIAGNOSTIC METHODS OF HEARTWORM DISEASE IN DOGS AND THEIR COMPARATIVE CHARACTERISTICS

The purpose of the work is to make a comparative description of methods of researching dogs for heartworm disease. The study was performed on dogs of different sexes, breeds and age groups whose owners went to the veterinary hospital. Conducted a general clinical examination, collected blood for testing in the morning or evening. Blood for the presence of larvae was examined by the method of Knot, crushed drop of blood, Hawk BV, staining for acid phosphatase. To identify parasitic adults, Dirofilaria immitis was examined for circulating antigen by rapid test systems. Conducted morphological and biochemical blood tests, electrocardiography, surgical removal of pseudotumors.

The efficiency of laboratory methods of research of dogs on heartworm disease was determined: research on circulating antigen - $100 \%$, Knott's method - $88.8 \%$ ( $p<0.05)$, crushed drop method - $72.2 \%$ ( $p<0.05)$, method Yastreba V. B. - $68.5 \%$ ( $p<0.001)$, and the method of staining for acid phosphatase - $55.5 \%(p<0.001)$ of dogs.

The study of blood morphology proved an increase in the number of eosinophils $16.3 \pm 2.7(p<0.01)$, a decrease in segmental neutrophils $55.0 \pm 3.5(p<0.05)$, which indicates allergy of animals due to the presence of antigen.

In dogs with heartworm disease, an increase in alkaline phosphatase activity was found - 185.7 \pm 5.4 IU/I $(p<0.05)$, GammaGlutamyltransferase 6.7 \pm 0.4 ( $p<0.05)$, which indicates liver dysfunction.

Electrocardiography revealed arrhythmia and conduction of the heart, which manifested itself as follows: sinus tachycardia $54 \%$, atrial fibrillation $4 \%$, extrasystole $10 \%$, ventricular fibrillation $2 \%$, right bundle branch block $5 \%$.

The pseudotumor, which located in the area of the dog's testis, was examination and surgically removed Dirofilaria repens from the vaginal cavity of the testis.

Key words: heartworm disease, microdirophylaria, Dirofilaria immitis, Dirofilaria repens, research methods, dogs.

Дата надходження до редакції: 10.11.2020 р. 